\title{
Las Casas, Alonso de Sandoval e a defesa da escravidão negra
}

\section{Las Casas, Alonso de Sandoval and the defense of black slavery}

\author{
Juliana Beatriz Almeida de Souza
}

David Brion Davis, nos anos 1960, alertava que muitos historiadores exageraram a antítese escravidão versus doutrina católica. A proposta deste artigo, nesse sentido, é a de se afastar de uma análise supervalorizadora, quer da atuação da Igreja católica na legitimação da escravidão negra, quer da sua defesa dos negros. ${ }^{1}$ Desse modo, buscar-se-á revisar a obra de dois missionários que atuaram na América espanhola e cumpriram importante papel na construção do discurso, ao mesmo tempo, legitimador e regulador do tráfico e da escravidão dos negros. Refiro-me ao dominicano Bartolomé de Las Casas, no século XVI, e ao jesuíta Alonso de Sandoval, no século XVII.

\section{Las Casas e a cegueira dos cristãos}

Bartolomé de Las Casas foi dos mais eminentes missionários na América ibérica. Nasceu em Sevilha, em $1484^{2}$. Ainda jovem, recebeu de seu pai, que voltava à Espanha, depois de acompanhar Colombo em sua segunda viagem à América, um índio escravo de presente. Pouco tempo depois, entretanto, teve que renunciar ao índio e devolvê-lo por ordem da rainha Isabel. À mesma época, estudava na Universidade de Salamanca, onde se licenciou em Direito. Em 1500, participou do refreamento de uma rebelião de mouros em Granada ${ }^{3}$. Dois anos depois, foi, com Nicolás de Ovando, ao Novo Mundo, pela primeira vez. Atuou no combate aos tainos em São Domingos. Não era ainda sacerdote. Da ilha de Hispaniola foi chamado à ilha de Cuba pelo governador Diego Velásquez, em razão 
dos seus serviços de justiça ${ }^{4}$. Las Casas recebeu uma encomienda ${ }^{5}$, próximo a Xagua, que deveria dividir com Pedro de Rentería ${ }^{6}$, e manteve a seu cargo por cerca de uma década. Nesses primeiros anos do século XVI, possivelmente em 1507, em Roma, foi ordenado sacerdote ${ }^{7}$. Estava de volta a São Domingos em 1509. Mais tarde, entrou em contato com os dominicanos que chegaram à América em setembro de $1510^{8}$.

Em 21 de dezembro de 1511, já ordenado e ainda encomendero, ouviu, em São Domingos, o sermão do dominicano Antonio de Montesinos contra os abusos da exploração do trabalho indígena que o marcaria fortemente. O frei, em sua homilia, segundo relato do próprio Las Casas, perguntava com que direito eram mantidos os índios em tão cruel servidão. Com que autoridade se fazia guerras contra aquela gente que estava pacífica e tranqüilamente em suas terras??

No mesmo ano, foi a Cuba na expedição de Pánfilo Narvaez como capelão da frota e assistiu de perto os maus-tratos de encomenderos em relação aos indígenas. Mais tarde, escreveria: "enquanto eu estava em Cuba, 7.000 crianças morreram em três meses. Algumas mães chegavam a afogar os filhos por desespero, enquanto outras, vendo-se grávidas, provocavam abortos com certas ervas" ${ }^{10}$. Foi ainda testemunha do massacre de Caonao, quando os espanhóis atacaram os índios sem motivo algum aparente, além de, como ele descreveu, verificar o quão amoladas estavam suas espadas.

Em 1514, a 15 de agosto, dia da celebração da Assunção da Virgem, renunciou a sua encomienda em um sermão, convertendo-se à causa indígena e iniciando aí suas prédicas contra as crueldades dos espanhóis frente aos ameríndios. Começava, igualmente, uma série de idas e vindas entre a Espanha e a América, buscando sensibilizar a Coroa espanhola a favor de uma colonização pacífica, como a que intentaria na região de Cumaná, norte da Venezuela, na qual clérigos e camponeses-colonos espanhóis substituiriam os soldados. A experiência, entretanto, resultou em total fracasso, em 1521, com sublevação de índios e morte de religiosos ${ }^{11}$.

Foi nessa época, também, que sustentou ser de melhor proveito para a Coroa substituir os índios por "negros ou outros escravos das minas". Com eles, pensava, se obteria muito mais ouro do que com os índios. Em princípios de 1516, esteve com o cardeal Cisneros e o teria influenciado sobre a política colonial e se assegurado da nomeação de monges jerônimos 
que foram enviados para estudar e reformar as condições na América ${ }^{12}$. Las Casas teria elaborado uma instrução entregue pelo cardeal Cisneros aos três monges, em que se admitia a entrada de escravos negros na América. Em junho do ano seguinte, em uma carta, os monges jerônimos aprovavam e recomendavam a introdução da escravidão negra. No mesmo ano, em um memorando, Las Casas propôs a Carlos V que cada colono tivesse escravos negros: dois homens e duas mulheres ${ }^{13}$. Em setembro de 1517, Las Casas foi nomeado "procurador dos índios" ${ }^{14}$ com salário de cem pesos anuais. Em 1518, em São Domingos, o juiz Alonso de Zuazo, nomeado juiz visitador no ano anterior, apontava a conveniência de substituir os índios pelos negros. Se Las Casas escreveu ou não a instrução de 1516 é motivo de divergência entre os autores. Mas tenha ou não escrito, certo é que da idéia de levar escravos negros à América, ele não era um representante original, nem isolado. Nele, esse juízo combinava sua defesa dos índios com certa noção jurídico-religiosa que considerava legítima a sujeição de infiéis à escravidão, os quais, dessa forma, se beneficiariam com a tutela de senhores cristãos ${ }^{15}$.

De volta a São Domingos, em 1521, Las Casas se refugiou no convento dominicano e, em finais do ano seguinte, ingressava na Ordem dos Pregadores. Iniciava ali uma nova etapa de estudos teológicos e acúmulo de conhecimentos e manuscritos, aproveitados em suas futuras obras. Foi naquela década de vinte que, provavelmente, teria começado a elaborar sua História das Indias e a Apologética histórica, texto que decorreu de seu desejo de descrever as maravilhas do Novo Mundo e as excelências de seus habitantes no primeiro livro da História das Índias. $\mathrm{O}$ assunto se mostrou tão vasto que resolveu lhe dedicar uma obra em separado ${ }^{16}$.

No ano de 1530, foi à Espanha para se entrevistar com Carlos V e obter dele providências para ajudar os índios. De volta à América, se aplicou ao estudo de teologia na Guatemala e no México. De lá, se mudou para o Peru para organizar a província da Ordem com os freis presentes na região, mas não obteve êxito, voltando a Vera Cruz. É dessa época, possivelmente redigido em Oaxaca, em $1536^{17}$, o tratado Do único modo de atrair todas as gentes à verdadeira religião, onde expressou sua visão sobre a evangelização. Nessa obra, Las Casas não se fixou no caso concreto da América, movendo-se no campo das idéias ${ }^{18}$. Segundo Las Casas, o único 
procedimento para atrair os povos à verdadeira religião não poderia ser outro além daquele que se depreendia da doutrina de Cristo: a pregação do Evangelho pelos missionários, sem armas. Assim, só se podia influir seres racionais pela persuasão do entendimento que, suavemente, tocasse o coração e, sem pressa, sensibilizasse a vontade. Os ouvintes deveriam compreender que os pregadores não desejavam adquirir nenhum tipo de domínio sobre eles, nem ambicionavam nenhum tipo de riquezas. Por sua vez, os pregadores deveriam ser benignos com aqueles a quem ensinavam, por mais resistentes que estes fossem.

Desse modo, os gentios deveriam ser atraídos pela doçura, humildade, afabilidade e vida exemplar dos pregadores. Esses, por sua vez, deviam arder no mesmo amor pela humanidade que moveu São Paulo. Era esse amor que se poderia dizer que Las Casas tinha pelos índios. O amor da caridade, irmã da serenidade, da paciência e da bondade ${ }^{19}$. Dessa maneira, era contrária ao modo instituído por Cristo a evangelização que pressupunha submeter pela força, mediante a guerra ${ }^{20}$. Pensar, pois, que, pela guerra, se apartavam os obstáculos para predicar a fé era, para ele, uma afirmação desprovida de razão e em desacordo com os textos bíblicos e a tradição da Igreja. Por meio da guerra, só se podia fazer nascer o ressentimento e as conversões assim conseguidas eram falsas e motivadas pelo medo de maiores danos e piores perdas. A guerra contra gentios era, para ele, pois, inócua, e quem a fazia pecava mortalmente.

Se Do único modo foi escrito mesmo em 1536, o foi um ano antes da bula Sublimis Deus, de 1537, do papa Paulo III, e ainda que não se tenha notícia do conhecimento dessa obra pelo pontífice, é interessante pensar o quanto as postulaçóes de Las Casas podem ter ecoado em Roma ${ }^{21}$. A bula declarava os índios "como verdadeiros homens", livres e capazes para a fé cristã. E que os "índios e todos os demais povos" que viessem a ser conhecidos pelos cristãos, ainda que vivessem "fora da fé de Cristo", não eram nem deveriam "ser privados de liberdade e de propriedade de bens". Era, pois, proibida a escravidão indígena e insistia-se na sua conversão pela palavra e pelo bom exemplo ${ }^{22}$. Carlos V proibiu a aplicação da bula, por motivos de defesa do Padroado, mas, ainda assim, ela exerceu influência na América ${ }^{23}$. 
Em 1539, Las Casas foi encarregado pelo bispo da Guatemala, de quem tinha sido auxiliar no ofício pastoral, e por outros homens preocupados com a defesa dos índios, a ir à Espanha para recrutar missionários e solicitar, junto a Carlos V, leis e ordenanças que garantissem a liberdade dos índios. Teve que aguardar três anos para conseguir uma audiência com o rei que se encontrava fora da Espanha ${ }^{24}$. Foram esses anos de 15411543, os do contexto da preparação, promulgação e reforma das Leis Novas que buscaram, entre outras disposiçōes, regular a exploração de mão-deobra indígena, impedir novas encomiendas, a hereditariedade delas e a escravidão indígena. Também nesse período, Las Casas escreveu sua obra mais contundente e que, mais tarde, serviu de base para a chamada lenda negra da conquista espanhola: a Brevissima relação da destruição das Índias. O tratado foi tão bem aceito pelas nações rivais à Espanha que houve quem quisesse negar-lhe a paternidade do escrito, como o dominicano Juan Meléndez, autor da obra Verdadeiros tesouros das Indias, para quem a Brevissima teria sido escrita por um autor francês e impressa em uma tipografia de Lion e não de Sevilha ${ }^{25}$.

Ainda em 1544, foi nomeado bispo de Chiapas, voltando à América meses depois. Em 1546, se reunia a Junta eclesiástica do México, entre os meses de junho e outubro. Participaram da Junta os bispos Zumárraga, do México, Marroquín, da Guatemala, Zárate, de Oaxaca, Vasco de Quiroga, de Michoacán, além de Las Casas, que se incorporou ao grupo pouco depois do início dos trabalhos. Esteve entre as conclusóes da Junta a afirmação de que a legitimidade da presença espanhola na América era a conversão dos índios, por concessão da Santa Sé. E tal concessão não retirava dos índios seus estados e títulos legítimos. Os bispos insistiram ainda no caráter catequético da encomienda, pedindo aos encomenderos que requisitassem religiosos para instruir os índios ${ }^{26}$.

As Leis Novas não vigoraram e Las Casas retornou à Espanha em 1547, renunciando ao bispado em 1550 . No mesmo ano, manteve o famoso debate com o filósofo Gines Sepúlveda que traduziu a Política de Aristóteles para o latim e encontrou, nesse autor, a base de seu pensamento. Em Democrates alter. Das justas causas da guerra contra os indios afirmava o caráter superior da cultura hispânica e a observância pelos espanhóis do direito natural, desconhecido pelos indígenas. Para Sepúlveda, o esta- 
do natural das sociedades era a hierarquia, traduzida nos termos de superioridade e inferioridade. E devendo o superior governar o inferior, defendia o direito à guerra contra os índios e a superioridade natural dos espanhóis frente a eles. Seu tratado foi reprovado pelos teólogos das Universidades de Salamanca e de Alcalá, sendo desaconselhado sua difusão na Espanha.

Em 1549, Carlos V resolveu convocar uma Junta com os membros do Conselho das Índias, de outras corporações e com quatorze teólogos para definir se era adequado ou oportuno recorrer às armas para abrir os caminhos da evangelização. $\mathrm{O}$ debate se desdobrou em duas etapas: as primeiras sessóes se desenrolaram de agosto a setembro de 1550 e a segunda etapa, no ano seguinte, de abril a maio. O local do embate entre Las Casas e Sepúlveda foi a capela do convento de são Gregório, em Valladolid. Ao final da reunião, a Junta de teólogos e canonistas não fechou uma decisão, porém, a julgar pelo fato de Sepúlveda não ter obtido permissão para publicar seu livro, Las Casas teve, pelo menos naquele momento, a preferência das posições ${ }^{27}$.

Las Casas não voltaria mais ao Novo Mundo. Manteria na Espanha sua obra como consultor e, através dos seus escritos, a defesa do indígena. Parecia convencido de que o apoio político era fundamental para a ação evangelizadora e para o combate às práticas ainda presentes na América e consideradas, por ele, injustas. Assim, grande parte de sua atuação se deu junto às cortes, principalmente a partir de 1531 e, mais ainda, de 1547, quando regressou definitivamente à Espanha ${ }^{28}$.

Em 1566, escreveu dois documentos. Um dirigido, em abril, ao Papa Pio V e outro encaminhado, em julho, ao Conselho das Índias. Nos dois, expôs seu modo de pensar e reafirmava posições quanto às condições para promover o Evangelho. A Junta Magna, convocada pelo rei Felipe II, e reunida em Madri, entre julho e setembro de 1568, para organizar o governo na América espanhola e a Instrução pontifícia sobre o modo de tratar os indios do Novo Mundo enviada a Felipe II, durante a reunião da Junta Magna, podem ter sido respostas às súplicas de Las Casas ${ }^{29}$. Mas, dois anos antes disso, no mesmo mês de julho de 1566, Las Casas faleceu no convento dominicano de Nossa Senhora da Atocha, em Madrid ${ }^{30}$. 
Quando Las Casas morreu, deixou muitos papéis originais e documentos e, entre eles, um volumoso manuscrito cheio de correções e adições que fora sendo encorpado trabalhosamente por mais de trinta anos. Tratava-se da História das Índias, obra que, segundo seu plano, seria dividida em seis partes. A primeira abarcava o período de 1492 a 1500 e as partes seguintes se ocupariam cada uma delas de uma década até 1550 . Só realizou metade do plano, completando três livros, correspondendo até o ano de 1520. A morte lhe sobreveio antes que pudesse terminar ${ }^{31}$. O manuscrito, entretanto, estava precedido por uma carta de Las Casas na qual fixava que a obra só deveria ser publicada "passados quarenta anos, porque se Deus" determinasse destruir a Espanha, se visse que era pelas destruições que os espanhóis fizeram nas Índias e aparecesse "a razão de sua justiça" ${ }^{32}$. Seu desejo se cumpriu com sobras, pois mais de trezentos anos depois, só em 1875 , a obra seria publicada pela primeira vez.

Foi nos capítulos 17 a 27 do livro I da História das Indias em que Las Casas se deteve nas ações de espanhóis e portugueses na África, ajuizandoas. Esse bloco de capítulos, segundo Pérez Fernández, é uma longa digressão, redigida à parte e intercalada pelo próprio Las Casas, depois do capítulo 16, onde, em continuação ao capítulo anterior, refutava o juízo de serem as Índias ocidentais conhecidas desde os tempos antigos. Nesses capítulos 15 e 16, Las Casas se baseava em autores antigos para combater a opinião exposta por Gonzalo Fernández de Oviedo na sua História geral e natural das Índias Ocidentais. Assim, o hoje capítulo 28 era, antes do encaixe, o capítulo 17 e tal digressão, provavelmente, teve redação autônoma e foi escrita em Valladolid, em 1556. Deve ter sido acrescentada ao texto da História das Indias, em 1558 ou 1559, quando passou a limpo o manuscrito, já sem os capítulos extraídos para formar a Apologética História ${ }^{33}$.

No seu retorno à Espanha, em 1547, Las Casas passou por Lisboa. Para Pérez Fernández, teria se dirigido para lá justamente porque na viagem, ou pouco antes, passou a lhe preocupar o tema da escravidão dos negros. Em Lisboa, desejava informar-se sobre a licitude do tráfico e da escravidão na África. Assim, ali, ele teve contato com as crônicas reais portuguesas sobre o assunto ${ }^{34}$. Las Casas, portanto, nunca esteve na África. E foi a partir dessas leituras e das informações recebidas dos dominicanos portugueses e espanhóis sobre a experiência na África que se baseou para escrever os seus capítulos. 
Nesses onze capítulos, percebem-se dois momentos: nos primeiros, do 17 ao 21, Las Casas se ocupou das Ilhas Canárias, a disputa entre Portugal e Espanha pela sua posse e o comportamento dos espanhóis em relação aos guanches. Nos capítulos seguintes, do 22 ao 27, o foco voltouse para a África e a ação dos portugueses na costa ocidental daquele continente. Em ambos os blocos, não se limitou a uma mera descrição do avanço de ibéricos na conquista das ilhas e de territórios africanos.

Já no capítulo 17, Las Casas fez considerações sobre a guerra de conquista. Dizia ser "coisa por certo de grande pasmo que nos cristãos haja caído tanta cegueira". Apesar de terem "professado respeitar a lei natural e o Evangelho em seu batismo, e seguir, em tudo no que toca ao trato e à edificação dos outros homens" as obras de Cristo e de "convidarem, atraírem e ganharem, por paz, amor, mansidão e exemplos de virtude, à fé, ao culto, à obediência e à devoção do verdadeiro Deus e Redentor do mundo todos os infiéis", sem distinção de seita, religião ou costumes corruptos que pudessem ter, esqueciam da forma e do modelo pelo qual Cristo deu e instituiu a Igreja no mundo. Nas suas ações nas Canárias, os cristãos não seguiam aquela que deveria ser sua regra geral de fazer aos outros aquilo que quisessem que fosse feito a eles mesmos: "sem destrinças, seja com índios, gentios, gregos ou bárbaros", pois todos pertenciam a um só Senhor, como promulgava São Paulo. Não era lícito, dizia Las Casas, "invadir as terras onde vivem e onde estão seus reinos, indo desassossegá-los e conquistá-los”, isto é, tirar bens, escravizar e sujeitar, "sem considerar que são homens e que têm almas racionais”. Portanto, o caminho da violência, para ganhar para Cristo os infiéis, seguia uma trilha, segundo Las Casas, condenada pelos Evangelhos ${ }^{35}$.

No capítulo 18, Las Casas condenava o assalto dos portugueses nas ilhas, "como se fossem turcos ou mouros", e punha dúvida se o batismo não era distribuído sem prévia doutrina, "pois tudo aquilo eram roubos, violências e matanças". Dessa maneira, "os que não queriam aceitar a fé” tinham razão pelas ações dos pregadores e não se davam conta os portugueses de que, "aos olhos de Deus", "era pecado aquele sacrifício que lhe ofereciam, tão banhado em sangue humano"36. Mais adiante, no capítulo 19 , voltaria à carga na sua crítica, condenando aqueles que escravizavam os guanches, pois "infamavam o nome de Cristo e punham a religião 
cristã a feder e a causar aversão”, levantando obstáculos à conversão. A justificativa de que eram infiéis para invadir suas terras, guerrear contra eles, matá-los ou subjugá-los e cativá-los, dizia Las Casas, era contrária à caridade, "assim se cometendo grandes e gravíssimos pecados mortais e nascendo a obrigação da restituição, fizessem tais coisas franceses ou portugueses ou castelhanos”. E nem a boa intenção de levar-lhes a fé os desculparia, pois "Deus bem sabia" como suas intenções iam "repletas de cobiça e diabólica ambição para assenhorearem terras e gentes livres" ${ }^{37}$.

No capítulo 22, já voltado para os primeiros descobrimentos portugueses na África, Las Casas deixava mais claro sua visão sobre os limites da guerra justa. Ele voltava a se referir à cegueira que recaiu sobre os cristãos mundanos e que os levava a crer que "por serem infiéis os não batizados" lhes era "lícito assaltá-los, roubá-los, cativá-los e matá-los”. No entanto, mesmo mouros, surpreende-nos Las Casas, não deveriam sofrer tais ações, "pois não eram dos que pelas partes da Berberia e do Levante infestam e fazem dano à cristandade, eram outras gentes, diferentes daquelas". E, sendo assim, bastava não terem as terras cristãs, "que o não eram as de Etiópia”, nem fazerem ou poderem fazer guerra contra os cristãos, nem terem ante eles qualquer obrigação para que os portugueses, para o bem da salvação de suas almas, fossem obrigados "a não fazer-lhes (sic) mal nenhum, mas, sim, a com eles tratarem pacificamente, dando-lhes exemplo de cristandade". Assim, logo amariam a religião cristã e a Jesus Cristo ${ }^{38}$.

Os portugueses, entretanto, além de não ajudarem na afeição aos missionários e à religião, ainda criavam oportunidade dos mouros moverem guerra contra os negros, "sem justa causa, para os venderem como escravos”. Las Casas alertava, então, que qualquer cristão deveria ser temeroso e prudente no trato e comércio com infiéis ${ }^{39}$.

No capítulo 25, Las Casas explicitava as três causas que considerava justas para guerra. A primeira delas, diz ele, "é quando os infiéis impugnam, guerreiam e inquietam a cristandade no momento presente ou por hábito". E identificava esses infiéis: "os turcos e mouros da Berberia e do Oriente", contra os quais se podia mover guerra, mesmo quando eles cessassem de fazê-la, porque era sabido "por larguíssima experiência que a sua tenção" era condenarem os cristãos. Essa "guerra contra eles nem se pode chamar guerra, mas sim legítima e natural defesa”. A segunda causa dar-se- 
ia se "perseguirem, estorvarem ou impedirem maldosamente" a fé cristã. Nesse caso, não se podia "duvidar da guerra justa" que os cristãos podiam "mover a quaisquer infiéis". Las Casas ainda explicava que usara a expressão "maldosamente" para marcar que tal causa não se aplicava quando os infiéis "matassem e perseguissem os cristãos por males e prejuízos que injustamente deles houvessem recebido". E foi mais além, considerando, igualmente fora das justas razões, quando um missionário fosse morto, sem culpa própria, mas como membro da nação que ofendeu os infiéis. A terceira causa de se mover guerra contra quaisquer infiéis seria por eles deterem reinos cristãos ou outros bens e não os quisessem restituir. Entretanto, nesse caso, Las Casas ponderava a adequação de antes discutir e averiguar "a razão que lhe assiste e a culpa da outra" parte, sendo duvidosa "perante o consistório e o foro de Deus", a justiça de uma guerra com vistas apenas a recobrar um bem temporal.

Após considerar as causas da guerra justa, Las Casas concluiu não estar nenhuma dessas três causas presente na experiência dos portugueses na África. Como justificá-los, então? Las Casas já advertira que "a nenhum infiel, seja mouro, alárabe, turco, tártaro, índio ou de qualquer outra espécie”, não poderia o povo cristão mover guerra. Assim como justificar "tantos males e ofensas, tantas mortes e cativeiros, tantos escândalos e perdição de tantas almas como naquelas pobres gentes, ainda que fossem mouros? Só por serem infiéis? Grande ignorância e condenável cegueira foi esta certamente" ${ }^{30}$.

Ora, para além do seu único modo de conversão, é interessante notar também como transparece no discurso de Las Casas a visão de mundo da reconquista - da luta pela retomada dos territórios conquistados pelos mulçumanos - e, ao mesmo tempo, como ele se afasta da sua dimensão mais superficial. Eram àqueles que atentavam à cristandade que se podia fazer guerra e esses eram obviamente os mulçumanos, mas o fato de serem mulçumanos simplesmente já não era em si uma justificativa para subjugálos e cativá-los. Era preciso mais. Las Casas condenava, assim, a cegueira que não deixava ver que na África não se encontrava mera reprodução dos embates no Mediterrâneo entre a cristandade e a religião maometana. Uma nova situação se apresentava com novos personagens. Guanches e negros, assim como os índios da América, requisitavam, segundo o dominicano, uma via pacífica de evangelização. 
Para J. F. Marques, pode-se identificar, do ponto de vista missionário, três zonas geográficas de atuação na África. A primeira delas seria a região da diocese de Ceuta e Tânger, terra de cultura e fé mulçumana. Eram cidades-fortalezas isoladas, onde o catolicismo levado pelos missionários esteve sempre sitiado diante do poder mouro. A segunda zona ocuparia o extremo sul da Mauritânia, incorporando o reino de Benim ${ }^{41}$. Aí a influência árabe tinha penetrado com algum sucesso. Antes da expansão portuguesa, uma expansão interior mercantil mulçumana repercutiu, segundo A. Vasco Rodrigues, no plano cultural e no mundo das crenças. E era o mulçumano - mercador, guerreiro ou pregador do Islão -, inimigo tradicional dos portugueses, que lhe fazia concorrência na regiáo ${ }^{42}$. Desse modo, os portugueses já encontraram presente a idéia do monoteísmo em muitas áreas costeiras da África ocidental, mas passada pelos mouros, exercendo, pois, os princípios do Corão, anterior ao catolicismo português, uma poderosa influência nessas populações. A terceira zona identificada por J. F. Marques abrangia o reino do Congo e a ponta meridional costeira da África. A chegada ao Reino do Congo, depois de meio século de investidas para o reconhecimento da costa ocidental da África e do golfo da Guiné, revelou aos portugueses uma área na qual não havia a influência islâmica. No entanto, foi com a mentalidade da reconquista que os ibéricos se lançaram à expansão marítima e, dessa forma, como diz David Brion Davis, tanto em Portugal como em Espanha prevaleceu a tendência tradicional em associar os africanos aos mouros e, portanto, à infidelidade ameaçadora, mesmo quando concretamente não haviam tido contato com o islamismo ${ }^{43}$.

Vale notar aqui as diferentes imagens construídas em relação à África e à América. David Brion Davis percebeu a tendência de conquistadores e missionários em ver no Novo Mundo o antigo ideal de natureza não-corrompida. $\mathrm{O}$ "nativo americano parecia desfrutar da inocência e felicidade de uma era anterior à queda do homem" ${ }^{4}$. Sendo assim, convertê-lo à fé cristã não necessariamente requeria a escravidão. $\mathrm{O}$ mesmo não acontecia em relação aos negros. Desse modo, um corpo de legislaçôes foi criado para proteger os índios da exploração colonizadora, enquanto o mesmo não era feito em relação aos negros. Pode-se mesmo dizer que, desafortunadamente, os impedimentos à escravidão indígena contribuíram para o crescimento da 
demanda por negros escravos. E, sendo assim, outros advogados dos índios, como bispo Diego de Landa, da Nova Espanha, foram defensores da escravidão negra. A discriminação de negros e índios pesava mais sobre aqueles do que estes e levou a um entendimento de que os negros haviam nascido para ser escravos e eram essencialmente inferiores tanto aos brancos quanto aos índios ${ }^{45}$.

Gomes Eanes de Zurara, um dos cronistas de Portugal citados por Las Casas nesses capítulos da História das Indias, foi, segundo Saunders, um dos grandes defensores da idéia de serem os africanos escravos por causa do pecado. Seguindo os filósofos escolásticos, acreditava que ao pecar o homem podia cair no estado servil e via justificativa na escravidão por ela poder transformar os negros em cristãos e por poder fazer com que usufruíssem um nível superior de existência material. Para Saunders, no que respeita ao século XVI, a justificação suprema para o tráfico de escravos era a que sustentava ser a escravização um método eficaz para levar a luz da fé cristã aos negros ${ }^{46}$.

Entretanto, Las Casas estava menos ligado ao discurso legitimador do tráfico e mais afeito à crítica das ações ibéricas na África. E mesmo se utilizando das informações de Gomes Eanes de Zurara no seu texto, não deixou de criticar sua insensibilidade em aceitar que os propósitos da Coroa portuguesa "não desculpavam os pecados da violência, as mortes e a danação dos que pereceram mortos sem fé nos sacramentos e que o cativeiro daqueles ali presentes não justificavam tamanha injustiça”. Mas Las Casas acreditava que esse era um erro daquele tempo em que escrevera Gomes Eanes de Zurara e rogava a Deus que isso não tivesse perdurado e se mantivesse até o momento em que ele próprio escrevia ${ }^{47}$.

Las Casas, portanto, na sua História das Índias, criticou, em primeiro lugar, a ação ibérica, especialmente, portuguesa, na África. E, nessa ação, viu o princípio da atuação espanhola na América. Foi essa "cegueira" que, para ele, tinha recaído sobre os cristãos e os fazia crer ser legítima a guerra contra infiéis, ainda que estes não os tivessem atacado ou posto a cristandade em perigo. Desse modo, penso, suas ponderaçôes estiveram temporal e argumentativamente próximas da crítica de meados do século XVI ao tráfico e à escravidão, centrada na maneira como tais processos ocorriam e preocupada em normalizar as relações aí inclusas. Tal discurso, con- 
cebido por religiosos ou não, não advogava o fim da escravidão negra, mas se inquietava com a maneira pela qual se aprisionavam os africanos, de modo a não pôr em risco a legitimidade do cativeiro na América. Las Casas antecipa, portanto, essa crítica na medida em que, ao discutir a guerra justa, encontra no aprisionamento na África a razão da injustiça da prática ibérica na escravização dos negros. No século XVII, aprofundarse-ia essa controvérsia, ganhando novas dimensões. A obra de Alonso de Sandoval representa esse novo enquadramento da questão.

\section{Sandoval e a estima dos jesuitas pelos negros}

Alonso de Sandoval nasceu em 1576, em Sevilha, como Las Casas. Ainda menino, migrou para o Peru com seus pais, onde seu pai assumiria o cargo de contador da Fazenda Real de Lima. Estudou no seminário de San Martín de Lima, onde teve conhecimentos de arte, teologia e moral. Era leitor de latim. Entrou para a Companhia de Jesus em 1593. Chegou a Cartagena de Índias em 1605 e, dali em diante, se ausentaria poucas vezes daquela cidade. No ano seguinte, acompanhou Diego de Torres à região de Urabá em uma missão sobre a qual escreveu uma relação ${ }^{48}$. Em 1607, participou de duas outras missóes: uma com o padre Juan António Santander, em Santa Marta, e a outra com o reitor do colégio jesuítico, padre Perlin, pelas regiōes da zona mineira Antioquia - Cáceres, Remedios e Zaragoza. Em 1617, foi a Lima e, em 1619, estava de volta a Cartagena. Naquele ano, fez a tradução da História da vida do padre Francisco Xavier, escrita pelo português João de Lucena e impressa em Lisboa em 1600. Era reitor do Colégio da Companhia de Jesus de Cartagena quando morreu, em 1651.

Nos dois anos em que esteve em Lima, buscou documentos e bibliografia e, provavelmente, começou a escrever sua obra maior Naturaleza, policia sagrada y profana, costumbres y ritos, disciplina y catecismo evangélico de todos etíopes que concluiu em 1623. A obra foi impressa em Sevilha, em 1627, e ficou mais conhecida pelo título em latim De instauranda Ethiopum salute, como aparece no privilégio real de 1625, reconhecendo sua autoria e no título da segunda edição de $1647^{49}$. O título, como a concepção do livro, parece inspirado na obra de outro jesuíta, José de 
Acosta, autor do De procuranda Indorum salute, tratado sobre a evangelização na América com considerações sobre as populações indígenas do Peru, publicado em Salamanca em $1589^{50}$.

De instauranda é considerado um dos mais importantes textos para a etnografia africana e afro-americana, publicados no período. E possivelmente o primeiro dos escritos em que aparecem preocupaçóes coerentes com um plano de ação em relação ao governo dos escravos ${ }^{51}$, depois de, no século XVI, as discussóes estarem centradas na legitimidade de se cativar os negros. Logo nas primeiras páginas, Sandoval dizia que "todo o assunto da obra" se dirigia ao "altíssimo e entre os divinos diviníssimo fim" de salvar as almas e, dentre elas, as mais destituídas de discernimento era a dos etíopes, "cuja rudeza, nudez e mau cheiro" costumavam fazer desistir o mais fervoroso missionário. Mas não era essa, alertava, a maior dificuldade se não as do "exercício exato de seus catecismos, no averiguar seus batismos e revalidar os inválidos, no administrar-lhes os demais Sacramentos e fazer-lhes capazes para que válida e proveitosamente" 52 os recebessem.

Sua obra está dividida em quatro livros, precedidos cada um deles por um resumo do seu argumento ${ }^{53}$. No livro primeiro da obra, o jesuíta faz uma extensa descrição das principais nações africanas, suas origens, seus costumes, suas tradiçóes. "Reinos de Etíopes que comumente descobriu a nação portuguesa” e que, para Sandoval, diversamente de Las Casas, era "tão benemérita nesta parte da Igreja Católica" ${ }^{54}$. Porém, como Las Casas, Sandoval nunca esteve na África e baseou suas informações em cartas e documentos que teve acesso. No livro segundo, novamente eram contemplados as origens, costumes, crenças, tradições e particularidades de vários reinos, povos do sul da Índia e das Filipinas, todos tidos por negros por Sandoval. Ademais, relatou os males que sofriam os negros na América: maus tratos dos espanhóis e a dificuldade em ter acesso aos sacramentos, impedidos pelos seus senhores. E ditava normas de comportamento para senhores e escravos. $\mathrm{O}$ terceiro livro se configurou em uma verdadeira metodologia catequética, retirada de sua experiência pessoal. Ali, examinou as maneiras de administração dos batismos e do catecismo. No último livro, Sandoval fez uma apologia à atuação da Companhia de Jesus, especialmente, em relação aos negros. 
Já no primeiro livro, aparecia a questão de fundo que parece ter movido Sandoval a escrever sua obra: por que a África permaneceu tanto tempo apartada da evangelização? Assim, Sandoval se preocupava em reverter esse afastamento, garantindo aos negros na América o conhecimento da religião. Dessa maneira, defendia que, pela escravidão dos negros na América, dava-se a eles a oportunidade de serem evangelizados e afastados dos erros a que estavam submetidos em suas nações de origem.

Para Sandoval, a escravidão negra era, portanto, justificável. E fez suas as causas de legitimidade previstas nas leis das Siete Partidas ${ }^{55}$ de Alfonso X de Castela, compiladas entre 1256 - 126356. Segundo as Siete Partidas, a escravidão era considerada "a coisa mais perversa e desprezível" que se poderia encontrar entre os homens, entretanto, ao mesmo tempo, a admitia quando se originava na guerra, pela venda própria ou pelo nascimento escravo. E aceitando a instituição, tratava de regulá-la "para garantir os direitos dados por Deus ao escravo" ${ }^{57}$. Sandoval considerava a questão da justificativa do cativeiro árdua, deixando sua determinação aos "doutores que tão douta e acertadamente escreveram a cerca deste ponto" 58 . E percebe-se na sua obra a filiação, por exemplo, às conclusões do tratado De iustitia et iure do dominicano Domingo de Soto, de 1553, da Suma de tratos y contratos do também dominicano Tomás de Mercado, de 1569 e da obra em seis volumes De iustitia et iure do jesuíta Luis de Molina, publicada entre 1593-160959.

Ainda no primeiro livro, Sandoval se colocava a questão da habitabilidade das zonas tórridas e relacionava a cor negra dos africanos à descendência de Cam. Segundo o autor, a tez negra provinha de uma qualidade predominante, nata e intrínseca, com qual Cam foi criado por Deus, isto é, um excessivo calor. Assim, seus descendentes saíram com a tez e com a marca desse homem que riu de seu pai com tanto atrevimento ${ }^{60}$. Sandoval lembrava que, segundo santo Ambrósio, o nome Cam queria dizer calidus, isto é, calor. A ofensa de Cam contra seu pai não só acarretou sua descendência escura, assim como a tornou sujeita ao cativeiro, à perpétua servidão ${ }^{61}$. Como diz o livro do Gênesis: "Maldito seja Canaã! Que ele seja, para seus irmãos, o último dos escravos" (Gen 9, 25) 2 .

Sandoval criticou a visão de que a liberdade fosse parte do direito natural, pois, se assim o fosse, não a podiam ter feito lícita o direito posi- 
tivo, nem o das gentes. Dizia que a natureza nunca mandou que fossem livres os homens e, por isso, deu lugar para que os direitos dos homens introduzissem a servidão sem contradizer os direitos naturais ${ }^{63}$. E exemplificava situações em que se perdia a liberdade por punição ao furto; por necessidade grave, quando os homens vendiam a si mesmos e a seus filhos; por derrota em guerras, quando cidades ou províncias tornavam-se subjugadas às leis da outra República. Exemplos oferecidos por autores antigos e pelas Sagradas Escrituras. A escravidão, pois, era apresentada como lícita e questionava-se Sandoval: se era justo os homens perderem a vida por causa dos seus delitos, não o seria que perdessem, por causa deles, a liberdade, de menor valor do que a vida ${ }^{64}$ ?

Assim, diz Sandoval que convinha ao mundo a servidão, pois a igualdade nos homens fora prejudicial e nela não se pode conservar o mundo. E, seguindo santo Agostinho, considerou necessário que uns mandassem e outros obedecessem, uns fossem senhores e outros, súditos. E, para que ao leitor isso parecesse ainda mais claro, Sandoval usou a metáfora do corpo humano, dizendo serem as partes interiores do corpo servidas pelas exteriores. O coração, como rei do corpo, era, assim, por todas as outras partes servido e "como absoluto senhor, envia seus espíritos vitais a todas" as partes, "vivificando-as, e governando-as, de modo que não há parte em todo o corpo, nem interior, nem exterior, que não esteja organizada para a conservação de tão principal membro" ${ }^{65}$.

O uso da metáfora do corpo humano, filiada ao pensamento aristotélico, foi corrente entre os pensadores cristãos na Idade Média para caracterizar a Igreja católica. O pensamento medieval era dominado pela existência de uma ordem universal em que cada parte cooperava de forma diferente na realização do cosmos. No século XVII, tal metáfora continuava a ser utilizada e, em especial, em relação à hierarquizada ordem do mundo social e político. A sociedade moderna concebia a si mesma como um corpo e, como tal, sua constituição provinha da natureza ${ }^{66}$. Mario Cesareo, no entanto, considera que muitos fatores "fizeram do corpo um espaço simbólico e instrumental privilegiado pelo discurso e pela prática religiosa colonial”. Foram eles, para o autor, a ausência massiva da instituição eclesiástica e o caráter individual da empresa evangelizadora; a vivência missionária como situação limite sobrelevada pelo corpo pela debi- 
lidade física, proliferação de doenças, entre outras causas; o estabelecimento de relações com o nativo que expunha sua nudez sem mediaçōes; a premência do interesse e poder individuais frente ao edifício jurídico falho; a crise geral do marco epistemológico europeu; e, finalmente, a importância do corpo sofredor de Cristo como modelo fundamental na tradição católica. Todos esses fatores apontam para o corpo como espaço simbólico onde cruzavam as tensões entre a realidade mercantil e o projeto utópico da missão ${ }^{67}$.

Sandoval ainda considerou que, como havia notado Aristóteles, os rudes e de curta inteligência, pela razão, deviam servir aos sábios e discretos, para que os governassem e lhes ensinassem algum modo de viver virtuoso. Tal idéia, pois, aplicada aos negros, tornava a servidão um meio efetivo para o conhecimento da verdadeira fé e de uma melhora nas suas condiçôes de vida, ou quem haveria de ser "tão cego" para não perceber "as grandes misericórdias" de Deus com os "homens boçais, por meio da escravidão. A cegueira, aqui, pois, para Sandoval, estava em não perceber que, através da escravidão, os negros eram levados "ao poder de senhores cristãos" que lhes davam a "luz do Evangelho, batizando-os e mantendoos na Fé" e conseguindo "a salvação de suas almas". E se eles estivessem em liberdade? Não teriam se "perdido miseravelmente" 68 ?

Nas Escrituras, Sandoval encontrou argumento para ligar a escravidão aos negros de forma irremediável ao dizer que Deus, "eterna verdade, para repreender a ingratidão, mal natural, e piores costumes do povo de Israel, lhes elevou seu sentimento, e os pecados deles", comparando-os aos "filhos dos Etíopes", maior opróbrio que se costumava dizer a quem nos desagrada: Não sois para mim como os etíopes, ó filhos de Israel? (Am 9, 7). Diz Sandoval que nas "divinas letras", não poucas vezes, se usava das palavras negro e etíope como sinônimos de pecador e mau" ${ }^{69}$.

Mas se Sandoval não contestou a validade da escravatura e buscou recursos para legitimar a escravidão negra, ele tinha preocupações pela maneira como se dava o aprisionamento dos negros na África e o subseqüente tráfico. Para Luis de Molina, que, como Las Casas, denunciou o aumento do número de negros feitos cativos com a chegada dos navios portugueses aos portos ou rios na África, o tráfico era lícito se a compra, na impossibilidade de averiguar as condições do aprisionamento, era feita 
de boa fé. Sandoval concordaria com essa idéia e daria menos responsabilidade aos que compravam de terceiros, pois o compromisso pela averiguação e a proibição de comprar escravos irregularmente submetidos era próprio aos comerciantes ${ }^{70}$. Desse modo, se inclinou à opinião do padre Luis Brandão, reitor do colégio jesuíta São Paulo, em Luanda. Luis Brandão, em uma carta de agosto de 1611, afirmava a Sandoval que os jesuítas ali e no Brasil compravam escravos para seu serviço sem nenhum escrúpulo. E se alguém poderia ter escrúpulo nessa compra seriam os moradores daquelas partes, nunca os que compravam dos mercadores fora dali. Os mercadores levavam, segundo Luis Brandão, os negros com boa fé e, assim, "muito bem se pode comprar a tais mercadores sem escrúpulo nenhum e eles os podem vender, porque é comum opinião que o possuidor de uma coisa com boa fé a pode vender e pode comprar"71. Além do mais, nenhum negro diria que foi aprisionado legalmente, mas eram poucos os que eram capturados ilicitamente ou condenados injustamente. Para o reitor jesuíta, perder tantas almas que saíam da África, das quais muitas se salvavam, por serem algumas erroneamente aprisionadas, sem saber quais eram, parecia não ser tão a favor do serviço de Deus: eram poucos os feito cativos injustamente e muitas as almas salvas e por retas razões aprisionadas. $\mathrm{O}$ tráfico, portanto, era justificado, pois promovia a propagação do catolicismo. Para o Conselho das Índias, "mesmo se as origens da servidão dos negros não era estritamente legítima", "o tráfico de escravos não podia ser interrompido sem pôr em risco a sobrevivência das colônias e, conseqüentemente, a propagação da verdadeira fé"72.

Não menor foi a atenção de Sandoval em normatizar as relações entre senhores e escravos. Para ele, senhores de escravos tinham deveres. Se aos escravos cabia obedecer, Sandoval, utilizando novamente a metáfora do corpo humano e comparando os escravos aos pés, recomendava aos senhores tratá-los com consideração, dando-lhes o descanso e honra que mereciam por seu serviço. Dizia Sandoval ser "verdade que os pés no corpo são pés", mas para andar eram tão importantes quanto o eram os olhos para ver e, porque eram pés, não os cortais, nem os maltratais, mas, ao contrário, procurais abrigá-los e limpá-los e curá-los quando enfermos, "com tanto cuidado como a carne vossa, e parte de vosso corpo". Do mesmo modo, deviam os senhores ter com seus escravos, como eram eles seus pés, consideração no governo do seu serviço ${ }^{73}$. 
Aos escravos recomendava obedecer a seus "senhores temporais" e aos senhores guardar com seus escravos a lei natural ${ }^{74}$. "Tudo aquilo, portanto, que quereis que os homens vos façam, fazei-o vós a eles, pois esta é a Lei e os Profetas" $(\mathrm{Mt} 7,12)^{75}$. E, lembrando santo Ambrósio, dizia não ser a condição e estado baixo do homem impedimento para que fosse estimado, do mesmo modo que a linhagem real não era garantia de loas. No entanto, o era, sim, a fé, porque o escravo e o livre eram a mesma coisa em Cristo e cada um receberia o prêmio do bem ou do mal que tivessem feito. Diante de Deus, a escravidão e a liberdade tinham o mesmo peso e, assim, a maior dignidade de todas era, concluía, a de servir a Cristo ${ }^{76}$. Ao que tudo indicava, então, o bom governo dos escravos era importante para os fins da colonização e da evangelização dos negros, mas não o deixava de ser para os próprios senhores cristãos, pois era de muito valor, diante dos olhos de Deus, o empenho em "ganhar almas e almas tão miseráveis e desditadas, como de escravos destituídos de todo bem"77.

A defesa da escravidão esteve entrelaçada com conceitos religiosos e este amálgama, que se desenvolvera na Antiguidade, estava prefigurado no judaísmo e na filosofia grega. A escravidão, desse modo, em um certo sentido, podia ser vista, como já foi apontado, como uma punição resultante do pecado ou de um defeito natural da alma que impedia uma conduta virtuosa. Era também vista como um modelo de dependência e de submissão. Mas, ainda em outro sentido, a escravidão situava-se como ponto de partida para uma missão divina. Se fora da escravidão do corpo corrompido de Adão que Cristo redimira a humanidade ${ }^{78}$, era por meio da escravidão que se poderia conduzir os negros ao caminho da salvação eterna.

O autor ainda se ocupou da pregação do apóstolo são Tomé no Oriente e também na América. E informava sobre as conversões promovidas pelo trabalho missionário de São Francisco Xavier que considerou ter seguido as pegadas de são Tomé. E dava notícias sobre o reino de Preste João. Sandoval localizava naquelas regiōes a antiguidade da presença da religião cristã e do trabalho pioneiro de religiosos. Também tratou da monstruosidade presente entre os homens da África e Ásia para, em seguida, passar às maravilhas da natureza. Seguiu, nesse tópico, a estratégia de missionários na América para comprovar a presença do demônio, buscando, pela recriação também dos mitos fantásticos da África, provar a necessidade de 
evangelizar os negros que vinham à América ${ }^{79}$. Para Sandoval, a ajuda espiritual se devia iniciar nos portos africanos de embarque e nos portos de chegada na América, notadamente Cartagena, sua região de atuação. Cartagena tinha um dos principais portos de entrada de africanos no continente e foi, junto com Vera Cruz, na Nova Espanha, e Porto Belo, no istmo panamenho, um dos três portos autorizados pela Coroa espanhola para receber mercadorias, incluindo aí os escravos.

Um dos temas mais difíceis para os missionários e que preocupava Sandoval e, como já se apontou, aparecera nas suas primeiras páginas, era averiguar a validade dos batismos dos africanos que chegavam à América. Domingo de Soto considerava que não se podia impor o batismo à força, nem subjugar os infiéis pelas armas para que abraçassem espontaneamente o batismo. Semelhante era a posição do dominicano Fernando de Oliveira que, em sua Arte de Guerra no Mar, publicado em 1555, considerou não haver guerra justa contra aqueles que não tinham sido batizados. Atacá-los e escravizá-los, dizia, era verdadeira tirania ${ }^{80}$. No caso dos negros que chegavam a Cartagena, para Sandoval, a maioria não havia sido batizada. Alguns até tinham recebido a água do batismo sobre a cabeça, mas muitos poucos haviam recebido validamente tal sacramento, "porta da salvação" 81. Las Casas, como se viu, se preocupou com o tema igualmente e também questionava se os batismos feitos em África eram antecedidos da devida doutrinação.

Sandoval narrou também a dificuldade em catequizar os negros com a ajuda dos intérpretes que, com freqüência, ou se cansavam de traduzir, ou mudavam as palavras, ou não estavam presentes nas horas do catecismo. Se não havia tempo para uma catequese detida, pela ameaça de morte ou por outras causas, Sandoval lembrava ser necessário ensinar-lhes brevemente seis verdades antes do batismo: 1. que existe Deus; 2. que Deus é remunerador; 3. que Deus é uno criador de tudo; 4. que Deus é graça e perdoa; 5. a imortalidade da alma; 6. o que é o pecado ${ }^{82}$.

No livro terceiro, ao considerar as questóes ligadas à conversão dos negros, Sandoval tratou de um outro tema: o reconhecimento de personagens ilustres e de santos negros. $\mathrm{O}$ autor oferecia as histórias das santidades da rainha de Sabá, de Baltazar, um dos três reis magos, de Ifigênia, princesa da Etiópia, Elesbão, rei da Etiópia, Antonio e Benedito, religiosos da Ordem Seráfica, entre outros ${ }^{83}$, e, com isso, demonstrava a 
potencialidade dos negros para abraçar a fé cristã e apontava para uma importante estratégia de evangelização: a difusão do culto a esses santos entre os negros como forma de aproximação destes com a religião católica, através de uma possível criação de laços de identidade.

Finalmente, o livro quarto estava dedicado a expor a grande estima que a Companhia de Jesus teve sempre para com os negros e o esforço com que havia se dedicado à sua evangelização. No argumento desse quarto livro, Sandoval dizia querer falar com seus irmãos e padres, "mais particular e domesticamente" ${ }^{44}$. Mudando, portanto, o foco da sua análise, Sandoval buscava demonstrar para seus irmãos jesuítas o quanto a Companhia era talhada para o ministério dos negros, ou mesmo predestinada, como testemunhava o fato de São Francisco Xavier ter nascido em Navarra, no mesmo ano do "descobrimento da Índia", 1497, "porque se entendesse como tinha Deus lhe predestinado para levar o Evangelho e semear a Fé" naquelas longínquas regiōes habitadas especialmente pelos negros ${ }^{85}$.

Mas Sandoval desenvolveu três outros argumentos para demonstrar o apreço e a grande estima da Companhia pela salvação dos "etíopes”. O primeiro argumento de Sandoval era o de a Companhia, quando não tinha mais que dez irmãos, entender por tão importante a tarefa da "restauração da Fé" na Etiópia, que designou, desses dez irmãos, dois para atuarem naquelas regiōes, "restando para o resto do mundo somente oito" ${ }^{86}$. E tanta era a estima da Companhia que designou para a missão na Índia Oriental, cujos naturais Sandoval dizia serem todos negros ou mulatos, sua melhor peça: o padre Francisco Xavier. Assim, dava-se aos que mais estimava o ministério de quem mais se apreciava.

O segundo argumento de Sandoval era o de a Companhia, que tinha cerrado as portas para as dignidades e bispados, requisitando dos seus professos que fizessem um voto de não só não pretendê-las como de não aceitá-las, haver tornado-as aceitáveis ali. Mas que ficasse claro que a licença para tal aceite se dava não por honra, mas por horror, não por descanso, mas por trabalhos, não por liberdade, mas por cativeiros certos, não uma vida de delícias, mas por morte certa e rigorosa. "De sorte que as portas que nem Príncipes, nem reis, nem muitos Papas, puderam abrir, os pobres e desajeitados negros foram os primeiros que as abriram: porque os tem a Companhia por tão filhos que lhes fia a chave de tanta importância" ${ }^{87}$. 
Para demonstrar o terceiro argumento, Sandoval relatou uma série de casos de jesuítas que sofreram cativeiros ou foram mortos nas missōes da Etiópia, Guiné e outras províncias de nações negras. Apesar dessas ações dos negros, diz o autor não ter a Companhia desistido de enviar seus homens, nem de defender os negros, nem de convertê-los a Cristo, tornando-se "gloriosa mãe de gloriosos mártires" e, talvez, por isso "estime tanto o ministério de negros, porque lhe deu o primeiro mártir" e por "tanta honra" queira pagar com o trabalho incansável de seus filhos, "até derramar o sangue pela salvação" como verdadeiros jesuítas ${ }^{88}$. Ora, Sandoval expunha, desse modo, que a um jesuíta agradava o martírio, sendo a sua entrega total, o sacrifício de tudo em favor da conquista de almas, uma marca de distinção da Companhia. Como escreveria, anos mais tarde, Antonio Vieira, os dominicanos viviam para a Igreja, mas os jesuítas morriam por ela ${ }^{89}$.

Sandoval terminou o livro levantando razōes para a sua Ordem dar a salvação aos negros. $\mathrm{O}$ autor lembrava ser vocação da Companhia de Jesus correr por "diversas partes do mundo buscando almas necessitadas" 90 . Assim, sendo Cristo mercador para quem trabalhavam os padres e sendo as Índias terra de mercadores, os jesuítas, segundo Sandoval, eram capazes de, no "mar de mil dificuldades" sacar "pérolas de sumo valor (que são as almas redimidas com seu sangue) das conchas broncas e feias de corpos negros"91. Em outra passagem anterior, no livro segundo, escrevera que a natureza fez a uns inábeis para estudar ciências e deu a estes "forças corporais e habilidade para trabalhar e servir: e assim os chamavam os sábios antigos filhos da terra, dizendo que são como carvalhos e pedras que trabalhando não se cansam"92. O corpo cristão, sacrificial, portanto, implicava um corpo mercantil, instrumental, gerador de riquezas materiais, salvação e vida eterna ${ }^{93}$.

Mas o que mais parecia preocupar Sandoval e era apresentado como um motivo de vergonha era a ação dos mouros na "perversão destas nações de negros". Se os mouros corriam tantos riscos e se empenhavam tanto nessa tarefa "por um prêmio e galardão corruptível e de tão pouca duração", se perguntava Sandoval, por que os jesuítas não o fariam por um "prêmio e galardão tão grande e que vai durar para sempre"? Seria, segundo Sandoval, grande vergonha que fossem vencidos pelos mouros na empresa de salvação das almas ${ }^{94}$. 
Sandoval chegava ao fim do seu livro, portanto, recolocando em pauta a questão da luta contra os mouros e do dever de difusão da verdadeira Fé pelo mundo. Nesse momento, não mais para justificar a escravização dos negros, mas para lembrar aos missionários da ainda presente disputa por espaços com os tradicionais inimigos da fé católica.

\section{Cristianização, escravidão e ordem colonial}

A imagem construída no século XVI sobre a América, mundo idílico habitado por homens naturais, diferia daquela que se fez da África. $\mathrm{Na}$ África, contava pouco como as populações viviam e a organização política e social entre elas. Dos negros já se sabia há muito tempo na Europa. Tal notícia antecedera o movimento de expansão, conquistas e experiências colonizadoras ultramarinas. Eram conhecidos pela Bíblia e dos escritores da Antiguidade, ou mesmo através de viajantes vindos da costa subsaariana. Eram vistos como tendo rejeitado a fé católica, sendo, portanto, improvável a relação entre eles e a imagem de selvagens inocentes. Las Casas, quando fez as petições por escravos negros na América, estava imbuído desta visão sobre a África e sobre os negros.

Em relação aos índios, Las Casas reconheceu sua humanidade e a excelência da sua organização política e social desde cedo, no entanto, à parte toda defesa que possa se dizer que tenha feito dos índios, estes continuavam objetos da evangelização, inocentes, contra quem não se deveria fazer violência, mas que, sim, deveriam ser caridosa e pacificamente levados à conversão à única e verdadeira religião. Por mais mudanças que tenha sofrido seu comportamento - e não é demais lembrar que foi um encomendero - e por mais radicalizações que tenha assumido nas suas posições, sua visão do indígena esteve ligada aos interesses expansionistas da Coroa espanhola. A construção do seu discurso articulou a noção de guerra justa, provinda da Idade Média, o imaginário da Reconquista, ainda bastante vivo, razão dos embates contra os mouros no Mediterrâneo e na própria península ibérica até pouco antes de Colombo chegar à América, e o espírito de missão ${ }^{95}$. Francisco López de Gómara, crítico de suas obras, escreveria, em 1552, não haver uma boa conquista sem colonização e, se a terra não era conquistada, as pessoas não eram convertidas ${ }^{96}$. Las Casas, 
talvez, invertesse essa proposição, afirmando que a evangelização era o primeiro passo para a conquista. Conquista pacífica que levasse à incorporação de novos territórios pelo império espanhol ${ }^{97}$.

Assim, se em um primeiro momento defendeu a escravidão negra sem restrições, em meados dos anos 1540/1550 mudaria sua disposição. $\mathrm{Na}$ sua História das Indias, externou ter reconsiderado seus reiterados pedidos para se levar escravos negros para a América, entre 1516 e $1543^{98}$. Poucos anos depois, concluiria que a escravidão dos negros era tão tirânica quanto a dos índios, sendo a razão destes a mesma que daqueles ${ }^{99}$. Sua posição refletia, então, sua crítica ao que identificava como uma continuidade da "tirania" de portugueses e espanhóis nos dois lados do Atlântico, tendo sido a violência contra os índios precedida pela violência contra guanches e negros.

Pode-se, pois, como proponho, vincular os capítulos da História das Indias ao discurso contestador da maneira pela qual se dava o tráfico. $\mathrm{Na}$ trilha aberta por Las Casas, ainda no XVI, os dominicanos, principalmente, aprofundaram o discurso crítico ao tráfico e/ou o discurso de legitimação da escravidão negra. Além do já citado Tomás de Mercado, o nome de Bartolomé de Albornoz, autor de Arte de los contratos, publicado em 1573, em Valencia, deve ser lembrado. Se Tomás de Mercado considerou o tráfico um negócio mercantil, que deveria se sujeitar a determinadas regras, Albornoz foi responsável pelo, talvez, mais duro combate à ausência de causas justas para a escravidão negra, do seu tempo. Como a obra de Tomás de Mercado, a de Albornoz se inscreve na corrente moralizante hispânica, surgida com início do mercantilismo, para guiar a vida moral dos mercadores e traficantes. Além disso, tinha como objetivo ajudar os ministros do sacramento da confissão, podendo também ser incluída, pois, no gênero dos confessionários ${ }^{100}$. Os dominicanos, portanto, assumiram, no século XVI, a crítica à maneira como era feito o comércio de negros, mantendo vivo o debate pela normatização das relaçôes no tráfico e na exploração do trabalho servil do negro. Tal tema ganharia mais força entre os jesuítas no século seguinte.

Sandoval, acredito, representa um outro momento do discurso legitimador da escravidão negra. A obra de Sandoval mistura lenda, dados históricos e etnográficos, constituindo-se em um amplo tratado sobre os africanos, uma crônica sobre o tráfico e a escravidão na Nova Granada. 
Seguiu, em sua crítica, os dominicanos e mesmo jesuítas que refletiram sobre a questão e antecedeu aos jesuítas que atuaram na América portuguesa e, muito provavelmente, os influenciou na construção de suas obras em meados do século XVII. Para David Brading, o objetivo principal da De Instauranda não era denunciar a escravidão, admitida por ele, nem os maus tratos dos espanhóis em relação aos negros, mas o de descrever e defender seus métodos de catequese e atrair outros jesuítas a abraçar seu ministério. David Brading diz ser a vocação que distinguia os jesuítas, em relação às ordens mendicantes, seu sacrifício pela tarefa de ganhar almas e Sandoval exortava seus irmãos a buscar a glória no exercício da missionação junto aos negros ${ }^{101}$.

Desse modo, pode-se pensar como a De Instauranda representa a preocupação com o governo dos escravos, coadunado os interesses da colonização espanhola e os da expansão missionária católica. Em 1663, o dominicano Juan de Castro consideraria que a escravidão resultava ser uma instituição geradora de benefícios: para os negros, a possibilidade de participação na fé; para os colonos, porque os escravos eram mais aptos para o trabalho; e para a Coroa, porque o tráfico facilitava a conservação dos territórios ultramarinos ${ }^{102}$. Ronaldo Vainfas salienta que a obra de Sandoval, como a dos jesuítas na América portuguesa, apareceu em um momento de expansão e aumento da importância da escravidão negra para a economia colonial e paralelo recrudescimento de resistência negra à escravidão, de que eram exemplos os quilombos. $\mathrm{O}$ medo das sedições, portanto, teria direcionado o impulso de normatização das relações entre senhores e escravos em favor da ordem colonial ${ }^{103}$. A economia simbólica da salvação necessitava, como diz M. Cesareo, uma economia política que a institucionalizasse $e^{104}$.

Mas, mais do que isso: a obra de Sandoval é um testemunho do projeto escravista cristão dos jesuítas. Em 1599, os jesuítas Alonso de Medrano e Francisco Figueroa chegaram ao Novo Reino de Granada com o arcebispo de Santa Fé, Bartolomé Lobo Guerrero, trazendo um rigoroso plano de evangelização. A satisfação com o trabalho dos jesuítas junto às sociedades andinas levou o arcebispo a pedir a fundação de um Colégio da Companhia e o envio de mais missionários para consolidar a presença jesuítica naquele espaço ${ }^{105}$. A região, entretanto, impunha outros desafios: o maior deles, para Sandoval, atrair a atenção dos missionários para as 
populações negras que chegavam no porto de Cartagena. Seu esforço foi, pois, o de sistematizar sua experiência missionária, seguindo o projeto jesuíta de evangelização, projeto esse, segundo Luis Fernando Restrepo, que, "através de uma rigorosa aplicação dos sacramentos e o trabalho em línguas nativas, intentavam criar sujeitos modernos, disciplinados e produtivos. Desejar-se-ia criar precisamente os sujeitos ideais que o Estado e a economia coloniais demandavam"106. E no que se refere ao projeto escravista cristão dos jesuítas, penso, pode-se acrescentar o objetivo de conformação da ordem social através da legitimidade da instituição escravista pela sua cristianização. A conquista espiritual, nos termos propostos por Gruzinski, supunha o projeto humanista de criar um "homem novo". A cristianização inscrevia no tecido social e nos corpos dos indivíduos as regras básicas da sociedade colonial cristã. Ao lado da conquista das almas, dava-se uma conquista dos corpos com dimensão pública de participação na ética, educação, tradições, costumes e valores cristãos ${ }^{107}$. No caso dos negros, portanto, sua cristianização correspondia a um ajustamento ao seu lugar social inscrito pela escravidão.

As obras de Las Casas e de Sandoval representam dois momentos do debate acerca do tráfico e da escravidão negra. No primeiro prevalece a conexão, por um lado, entre a idéia de guerra justa e a legitimidade do tráfico e, por outro, a própria legitimidade da presença espanhola na América; no segundo, o projeto colonizador ibérico e, especificamente o projeto jesuíta de missionação e governo dos escravos. Em ambas, percebe-se a adequação de projetos e teorias forjadas em Espanha frente às vicissitudes apresentadas pela colonização da América e a harmonização entre os planos imperiais castelhanos e os da Igreja católica. São obras, portanto, que valem ser ainda exploradas por aqueles que se interessam pelo discurso legitimador da escravidão negra, pelos projetos de colonização, pelos planos missionários na América ibérica entre os séculos XVI e XVII.

\section{Notas}

${ }^{1}$ Versões preliminares e parciais deste artigo foram apresentadas no XXII Simpósio Nacional de História da ANPUH (2003), no II Simpósio Nacional de História Cultural (2004) e no XXIII Simpósio Nacional de História da ANPUH (2005). Agradeço a colaboração do aluno Wallace R. S. de Farias em parte da pesquisa. 
${ }^{2}$ Alguns autores afirmam que Las Casas nasceu em 1474, mas, segundo Isacio Pérez Fernández, pode-se afirmar "com segurança quase total" que 1484 foi o ano do seu nascimento. PÉREZ FERNÁNDEZ, Isacio, pe. Bartolomé de Las Casas: viajero por dos mundo. Su figura, su biografía sincera, su personalidad. Cuzco: CBC, 1998. p. 17.

${ }^{3}$ SARANYANA, Josep Ignasi (dir.). Teología en América Latina. Desde los orígenes a la Guerra de Sucesión (1493 -1715). Madrid/Frankfurt am Main: Iberoamericana/Vervuert, 1999. v. 1. p. 66.

${ }^{4}$ EGUIARA Y ERGUREN, Juan José de. Historia de sabios novohispanos. (1754) México: Universidad Nacional Autónoma de México, 1998. p. 28.

${ }^{5}$ A encomienda, segundo Bernand e Gruzinski, era uma instituição ibérica que foi transposta para as Antilhas por Nicolás de Ovando, governador de Hispaniola (1503) e para o México por Cortés. Na Espanha, a encomienda tinha sua raiz na Reconquista; na América, porém, a encomienda não correspondeu a uma dotação de terras, e, sim, à concessão pelo Estado de mão-de-obra compulsória. O encomendero tornou-se beneficiário do trabalho forçado dos índios: recebia dos indígenas tributo ou serviço pessoal e, em troca, devia prestar-lhes assistência material e religiosa. A queda considerável da população indígena e as críticas recebidas contribuíram para o declínio da instituição. Repartimiento e encomienda na América espanhola são, para esses autores, sinônimos, o primeiro termo acentuando o processo de distribuição, enquanto o segundo está ligado às responsabilidades do titular. No México, o repartimiento chamou-se também cuatéquil, no Peru, mita, e na Colômbia, concierto. GRUZINSKI, S., BERNAND, C.. História do Novo Mundo: da descoberta à conquista uma experiência européia, 1492-1550. São Paulo: Edusp, 1997. p. 606-607.

${ }^{6}$ ESTEVE BARBA, Francisco. Historiografia indiana. 2a. ed. Madrid: Editorial Gredos, 1992. p. 87.

${ }^{7}$ Não há certeza sobre a data e o local da ordenação sacerdotal de Las Casas. Cf. PÉREZ FERNÁNDEZ, Isacio, pe., op. cit., 1998, p. 31-35.

${ }^{8}$ THOMAS, Hugh. Quién es quién de los conquistadores. Espanha: Salvat, 2001. p. 383.

9 JOSAPHAT, Carlos, frei. Las Casas. Todos os direitos para todos. São Paulo: Edições Loyola, 2000. p. 53.

${ }^{10}$ CASAS, B. de las. Historia das Indias, II, 13 apud. TODOROV, T. A conquista da América: a questão do outro. São Paulo: Martins Fontes, 1988. p. 130, 136-137.

${ }^{11}$ BALLESTEROS, A. História da América. Espanha: s/ed., 1954. tomo XVII. p. 74-76.

${ }^{12}$ THOMAS, Hugh, op. cit., p. 384 - 385.

${ }^{13}$ A primeira autorização da Coroa espanhola para o tráfico de escravos negros foi em 1501. Dois anos depois, a licença foi revogada. Em 1510, voltou a conceder uma autorização que, com a morte do rei Fernando, foi suspensa pelo regente de Castela, o cardeal Cisneros. HÖFFNER, Joseph. Colonização e evangelização: ética da colonização espanhola no Século de Ouro. Rio de Janeiro: Presença, 1977. p. 173-174.

${ }^{14}$ THOMAS, Hugh, op. cit., p. 384.

TOPOI, v. 7, n. 12, jan.-jun. 2006, pp. 25-59. 
${ }^{15}$ ESTEVE BARBA, Francisco, op. cit., p. 88.

${ }^{16}$ ibid., p.98.

${ }^{17}$ SARANYANA, Josep Ignasi (dir.), op. cit., p. 66.

${ }^{18}$ ESTEVE BARBA, Francisco, op. cit., p. 94.

19 Todorov, em seu livro, avalia a relação entre o amor de Las Casas pelos índios e o conhecimento que tinha de suas culturas. Visto na perspectiva do amor caridoso, tal questão não se colocaria dessa maneira, uma vez que não se relacionaria com o reconhecimento de uma outra identidade, mas, sim, com o pertencimento a uma mesma unidade, a do corpo de Cristo. TODOROV, T., op. cit., p. 165-179. José Alves de Freitas Neto discute a relação entre amar e conhecer na visão de Todorov sobre Las Casas. NETO, José Alves de Freitas. Bartolomé de Las Casas: a narrativa trágica, o amor cristão e a memória americana. São Paulo: Annablume, 2003.

${ }^{20}$ PAGALDAY, José Ramon I., pe. "Bartolomeu de Las Casas e o seu conceito de evangelização". In: História da Evangelização na América Latina. São Paulo: Paulinas, 1988. p. 48. ESTEVE BARBA, Francisco, op. cit., 93-94.

${ }^{21}$ Existe um outro documento pontifício chamado Veritas ipsa que, parece, ao ter sido ampliado, ganhou o nome de Sublimis Deus. SUESS, Paulo (org.). A conquista espiritual da América espanhola. Petrópolis: Vozes, 1992. p. 275. Cf. também SARANYANA, Josep Ignasi (dir.), op. cit., p. 66 - 68; 101.

${ }^{22}$ Papa Paulo III. Sublimis Deus. 1537, apud. SUESS, Paulo (org.), op. cit., p. 273. Josaphat fala de uma estratégia de missionários, especialmente dominicanos, em informar ao papa sobre os dotes intelectuais, as qualidades morais e espirituais dos índios e dos progressos da evangelização na América. JOSAPHAT, Carlos, frei, op. cit., p. 101-105. Luis Martínez Ferrer e Carmen José Alejos-Grau destacam a participação do frei dominicano Bernardino de Minaya. SARANYANA, Josep Ignasi (dir.), op. cit., p. 101.

${ }^{23}$ SARANYANA, Josep Ignasi (dir.), op. cit., p. 101.

${ }^{24}$ EGUIARA Y ERGUREN, Juan José de, op. cit., p. 30.

25 ibid., p. 34-35.

${ }^{26}$ SARANYANA, Josep Ignasi (dir.), op. cit., p. 110.

${ }^{27}$ XIRAU, Ramón. Idea y querella de la Nueva España. Madrid: Alianza Editorial, 1973. p. 17; TODOROV, T., op. cit. , p. 148-153; JOSAPHAT, Carlos, frei, op. cit., p. $147-$ 155; ESTEVE BARBA, Francisco, op. cit., p. 90-91; PÉREZ FERNÁNDEZ, Isacio, pe., op. cit., 1998, p. 102-104.

${ }^{28}$ PAGALDAY, José Ramon I., pe., op. cit., p. 47.

${ }^{29}$ PÉREZ FERNÁNDEZ, Isacio, pe., op. cit., 1998, p. 129-131.

${ }^{30} \mathrm{O}$ verbete de Hugh Thomas sobre Las Casas serviu de fio condutor para a apresentação das referências biográficas. THOMAS, Hugh, op.cit.,p. 382-386.

${ }^{31}$ ESTEVE BARBA, Francisco, op. cit., p. 95.

32 PAGALDAY, José Ramon I., pe., op. cit., p. 45. 
33 PÉREZ FERNÁNDEZ, Isacio, pe. “Estudo preliminar”. In: CASAS, Bartolomé de las. Brevíssima relação da destruição de África. Lisboa: Edições Antígona, 1996. p. 22-35. ${ }^{34}$ PÉREZ FERNÁNDEZ, Isacio, pe., op. cit., 1998. p. 94.

${ }^{35}$ CASAS, Bartolomé de las. Brevíssima relação da destruição de África. Lisboa: Edições Antígona, 1996. p. 247-249.

${ }^{36}$ ibid., p. 255-256.

37 ibid., p. 274-275.

38 ibid., p. 298.

39 ibid., p. 298.

40 ibid., p. 322-326.

${ }^{41}$ MARQUES, João Francisco. A religião na expansão portuguesa. Vectores e itinerários da evangelização ultramarina: o paradigma do Congo. Revista de História das Idéias. Coimbra, vol. 14, 1992. p. 125-126.

${ }^{42}$ RODRIGUES, Adriano Vasco. "Aculturação artística e social no Reino do Congo resultante da evangelização após a chegada dos portugueses". In: Atas do congresso internacional Bartolomeu Dias e a sua época. Porto: Universidade do Porto/Comissão Nacional para as Comemorações dos Descobrimentos Portugueses, 1992. v. 5. p. 553.

${ }^{43}$ DAVIS, David Brion. O problema da escravidão na cultura ocidental. Rio de Janeiro: Civilização Brasileira, 2001. p. 209.

44 ibid., p. 195-196.

45 ibid., p. 199.

${ }^{46}$ SAUNDERS, A. C. de C. M.. História social dos escravos e libertos negros em Portugal (1441 - 1555). Lisboa, /Imprensa Nacional/Casa da Moeda, 1982. p. 66 - 68. David Brion Davis também demonstra essa explicação da origem da escravidão ligada ao pecado. DAVIS, David Brion, op. cit., p. 81 - 109. E Höffner diz que essa idéia de que a raiz da escravidão está no pecado "ficou definitivamente arraigada na teologia católica". HÖFFNER, Joseph, op. cit., p. 77.

${ }^{47}$ CASAS, Bartolomé de las, op. cit., p. 319.

${ }^{48}$ Relación de la misión y primera en Urubá que el padre Diego de Torres, viceprovincial de la Compañia de Jesús del Nuevo Reino y Quito, hizo la provincia de los indios infieles de Urubá por el año de 1606, scripta al padre Estebán Páez, provincial de Perú, por el padre Alonso de Sandoval que fue su compañero, em ARSI, Nuevo Reino y Quito, Epistolario general, Historia I.

${ }^{49} \mathrm{Na}$ primeira edição a obra intitulava-se Naturaleza, policia sagrada i profana, costumbres $i$ ritos, disciplina $i$ catecismo evangélico de todos etíopes [...] Já a edição de 1647 ganhou o título De instauranda Athiopum salute. Historia de Ethiopia, naturaleza, policia sagraday profana, costumbres, ritos y cathecismo evangélico de todos los Etiopes con que se reataura la salud de sus almas, dividida en dos tomos: ilustrados de nuevo en esta segunda impresión con cosas curiosas y indice muy copioso [...]. 
${ }^{50}$ SANDOVAL, Alonso. Un tratado sobre la esclavitud. [De instauranda Æthiopum salute] (introdução, transcrição e tradução de Enriqueta Vila Vilar) Madrid: Alianza Editorial, 1987. Introdução: p. 25 - 36. Cf. também SARANYANA, Josep Ignasi (dir.). op. cit., p. 252-255.

${ }^{51}$ Rafael de Bivar Marquese atribui ao dominicano Jean-Baptiste Du Tertre, autor de uma história das Antilhas francesas publicada entre 1667 e 1771, a "primeira abordagem sistemática da questão a ser publicada na Europa”. Entretanto, acredito que se possa dar tal primazia à obra de Alonso de Sandoval. MARQUESE, Rafael de Bivar. Feitores do corpo, missionários da mente: senhores, letrados e o controle dos escravos nas Américas, 16601860. São Paulo: Companhia das Letras, 2004. p. 26.

52 SANDOVAL, Alonso de. De instauranda athiopum salute. Madrid: Por Alonso de Paredes, 1647. Dedicatória. Foram usadas aqui duas edições do texto de Alonso de Sandoval. Na análise das três primeiras partes, foi utilizada a edição de 1647 , reproduzida no cd Afro-América: textos históricos. Introdução e seleção de Enriqueta Vila Vilar. Coleção Clássicos Tavera, dirigido por José Andres-Gallego. Fundação Histórica Tavera. Série II, v. 7; para o livro IV, a edição de 1627, com introdução, transcrição e tradução de Enriqueta Vila Vilar, publicado pela Alianza Editorial, em 1987.

${ }^{53}$ Há diferenças entre a primeira e a segunda ediçôes. Houve mudança do título da obra, como já foi referido, de títulos das partes e revisão de conteúdos por Sandoval, no intervalo entre as duas edições. Na primeira edição, o Livro primeiro se intitula De las principales naciones de Etiopes, que se conocen en el mundo, y de sus condiciones, ritos y abusos; $y$ de otras cosas notables, que se hallan en ellas; e na segunda edição, De los mas principales Reinos, y Provincias de Negros que se hallan en la Etiopia Occidental, o interior de la parte tercera del mundo, que ocupa el Africa. En que se trata con gran latitud de su esclavitud. O Livro segundo se intitula De los males que padecen estos negros y de la necessidad deste ministerio que los remedia, cuya alteza y excelencia resplandece por varios titulos; e na segunda edição, De los mas principales Reinos, Provincias e Islas de Negros que se hallan en Etiopia Oriental, o sobre Egipto, de la parte segunda del mundo que ocupa el Asia. Y de la predicación en toda ella del Apostol Santo Tomé. O livro terceiro, na edição de 1627, chama-se Del modo de ayudar a la salvacion de estos negros en los puertos de adonde salen y adonde llegan sus armazones; e na de 1647, De muchas cosas monstruosas, singulares e muy maravillosas que los Autores cuentan hallarse en los Reinos destos Etiopes $Y$ demás tierras de Negros. $Y$ de las vidas de sus Santos y Varones ilustres que se han podido rastrear.

${ }^{54}$ SANDOVAL, Alonso de, op.cit., 1647, p. 2.

55 ANDRÉS-GALLEGO, José, GARCÍA AÑOVEROS, Jesús María. La Iglesia y la esclavitud de los negros. Pamplona: EUNSA, 2002. p. 56.

${ }^{56}$ GRUZINSKI, S., BERNAND, C., op. cit., p. 627.

${ }^{57}$ PALACIOS PRECIADO, Jorge. La esclavitud de los africanos y la trata de negros. Entre teoría y la práctica. Tunja: Publicaciones del Magister en Historia - UPTC, 1998. (Nuevas lecturas de Historia, 2) p. 9.

${ }^{58}$ SANDOVAL, Alonso de, op.cit., 1647, p. 74.

TOPOI, v. 7, n. 12, jan.-jun. 2006, pp. 25-59. 
59 ANDRÉS-GALLEGO, José, GARCÍA AÑOVEROS, Jesús María, op.cit., p. 57-59; BOXER, Charles R. A Igreja e a expansão ibérica (1440-1770). Lisboa: Edições 70, 1989. p. 49.

${ }^{60}$ Segundo o relato bíblico, Noé, bebendo vinho, se embriagou e ficou nu dentro de sua tenda. Um de seus filhos, Cam, viu a nudez de seu pai e riu dela. Seus dois irmãos, Sem e Jafé, tomaram um manto e o cobriram, sem olhar a nudez de seu pai. Quando Noé acordou e soube da atitude de Cam, o amaldiçoou. (Gen 9, 18-27) A BÍBLIA de Jerusalém. São Paulo: Paulinas, 1989. p.43-44.

${ }^{61}$ SANDOVAL, Alonso de, op.cit., 1647, p. 16-21.

${ }^{62}$ A BÍBLIA de Jerusalém. São Paulo: Paulinas, 1989. p. 44.

${ }^{63}$ SANDOVAL, Alonso de, op.cit., 1647, p. 84.

${ }^{64}$ ibid., 1647 , p. 85.

65 ibid., 1647, p. 92.

${ }^{66}$ HESPANHA, Antonio Manuel, XAVIER, Ângela Barreto. "A representação da sociedade e do poder". In: MATTOSO, J.. História de Portugal. Lisboa: Editorial Estampa, 1993. Vol. 4: O Antigo Regime (1620-1807). p. 122.

${ }^{67}$ CESAREO, Mario. Cruzados, mártires y beatos. Indiana: Purdue Univesity Press, 1995. p. 21-22.

${ }^{68}$ SANDOVAL, Alonso de, op.cit., 1647, p. 86.

${ }^{69}$ ibid., p. 88.

${ }^{70}$ ANDRÉS-GALLEGO, José, GARCÍA AÑOVEROS, Jesús María, op.cit., p. 46-59.

${ }^{71}$ SANDOVAL, Alonso de, op.cit., 1647, p. 100.

72 DAVIS, David Brion, op. cit., p. 222- 23.

${ }^{73}$ SANDOVAL, Alonso de, op.cit., 1647, p. 75.

${ }^{74}$ ibid., p. 76.

${ }^{75}$ A BÍBLIA de Jerusalém, op.cit., p. 1850.

${ }^{76}$ SANDOVAL, Alonso de, op.cit., 1647, p. 77.

77 ibid., p. 80.

${ }^{78}$ DAVIS, David Brion, op. cit., p. 109.

79 SANDOVAL, Alonso de, op.cit., 1987, introdução: p. 37.

${ }^{80}$ Charles Boxer duvida da influência de Fernando de Oliveira em seus contemporâneos. BOXER, Charles R., op.cit., p. 48-49.

81 ibid., p. 421.

82 SARANYANA, Josep Ignasi, op.cit., p. 254-255.

${ }^{83}$ SANDOVAL, Alonso de, op.cit., 1647, p. 478-501.

${ }^{84}$ SANDOVAL, Alonso de, op.cit., 1987. p. 505.

85 ibid., p. 506. 
${ }^{86}$ ibid., p. 515-516.

${ }^{87}$ ibid., p. 518.

${ }^{88}$ ibid., p. 520.

${ }^{89}$ apud. BOXER, Charles R., op. cit., p. 88-89.

${ }^{90}$ SANDOVAL, Alonso de, op. cit., 1987. p. 608.

${ }^{91}$ ibid., p. 610.

92 SANDOVAL, Alonso de, op.cit., 1647, p. 93.

${ }^{94}$ SANDOVAL, Alonso de, op. cit., 1987. p. 612.

${ }^{55}$ Cf. NEVES, Luiz Felipe Baêta. O combate dos soldados de Cristo na terra dos papagaios: colonialismo e repressão cultural. Rio de Janeiro: Forense-Universitária, 1978.

${ }^{96}$ LÓPEZ de GÓMARA, Francisco. Historia general de las Indias. apud. ELLIOT, J. H. "A conquista espanhola e a colonização da América". In: BETHELL, L. (org.). História da América Latina. Volume 1: América Latina colonial. São Paulo/Brasília: Edusp/FUNAG, 1997. p. 135.

${ }^{97}$ Todorov diz que Las Casas partilhava da "ideologia colonialista", sendo, pois, defensor da submissão da América à Espanha. TODOROV, op. cit., p. 168-173.

${ }^{98}$ PÉREZ FERNÁNDEZ, Isacio, op. cit., 1991, p. 188.

${ }^{99}$ XIRAU, Ramón, op. cit., p. 18; HÖFFNER, Joseph, op. cit., p. 189.

${ }^{100}$ SARANYANA, Josep Ignasi (dir.). op. cit., p. 408.

${ }^{101}$ BRADING, David A. Orbe indiano. De la monarquía católica a la república criolla, 1492 -1867. México: FCE, 1991. p. 192-193.

102 apud. PALACIOS PRECIADO, Jorge, op. cit., p. 11-12.

${ }^{103}$ Cf. VAINFAS, R.. El proyecto de una esclavitud cristiana: ideas jesuiticas en Brasil y Cartagena de Indias durante el siglo XVII. Medellín, X Congreso de Historia de Colombia, 1997. mimeo. VAINFAS, R. "Deus contra Palmares". In: REIS, J.J., GOMES, F. dos S. Liberdade por um fio. São Paulo: Companhia das Letras, 1996. p. 60-80. Paulo de Assunção também, no que se refere à América portuguesa, discute a relação da atuação dos jesuítas e a economia colonial. Cf. ASSUNÇÃO, Paulo de. Negócios Jesuíticos. São Paulo: EDUSP, 2004.

${ }^{104}$ CESAREO, Mario, op. cit., p. 149.

${ }^{105}$ RESTREPO, Luis Fernando. "Los límites da la razón occidental: la 'naturaleza' muisca y los proyectos intelectuales de los jesuitas en el Nuevo Reino de Granada, siglo XVII”. In: MILLONES Figueroa, Luis, LEDEZMA, Domingo (eds.) El saber de los jesuitas, historias natulares y el Nuevo Mundo. Frankfurt/Madrid: Vervuert/Iberoamaericana, 2005. p. 176.

106 ibid., p. 174.

${ }^{107}$ GRUZINSKI, Serge. "Las repercusiones de la conquista: la experiencia novo hispana". In: BERNAND, Carmen (org.). Descubrimiento, conquista y colonización de América a quinientos años. México: Fondo de Cultura Económica, 1994. p. 163-164. 


\section{Referências bibliográficas}

ANDRÉS-GALLEGO, José, GARCÍA AÑOVEROS, Jesús María. La Iglesia y la esclavitud de los negros. Pamplona: EUNSA, 2002.

A BÍBLIA de Jerusalém. São Paulo: Paulinas, 1989.

BALLESTEROS, A. História da América. Espanha: s/ed., 1954. tomo XVII.

BETHELL, L. (org.). História da América Latina. Volume 1: América Latina colonial. São Paulo/Brasília: Edusp/FUNAG, 1997.

BRADING, David A. Orbe indiano. De la monarquía católica a la república criolla, 1492-1867. México: FCE, 1991.

BOXER, Charles R. A Igreja e a expansão ibérica (1440-1770). Lisboa: Edições 70, 1989.

CASAS, Bartolomé de las. Brevissima relação da destruição de África. Lisboa: Ediçōes Antígona, 1996.

CESAREO, Mario. Cruzados, mártires y beatos. Indiana: Purdue Univesity Press, 1995.

DAVIS, David Brion. O problema da escravidão na cultura ocidental. Rio de Janeiro: Civilização Brasileira, 2001.

EGUIARA Y ERGUREN, Juan José de. Historia de sabios novohispanos. (1754) México: Universidad Nacional Autónoma de México, 1998. p. 28.

ESTEVE BARBA, Francisco. Historiografia indiana. 2a . ed. Madrid: Editorial Gredos, 1992.

GRUZINSKI, Serge. "Las repercusiones de la conquista: la experiencia novo hispana”. In: BERNAND, Carmen (org.). Descubrimiento, conquista y colonización de América a quinientos años. México: Fondo de Cultura Económica, 1994. p. 148-171.

BERNAND, C. História do Novo Mundo: da descoberta à conquista uma experiência européia, 1492-1550. São Paulo: Edusp, 1997.

HÖFFNER, Joseph. Colonização e evangelização: ética da colonização espanhola no Século de Ouro. Rio de Janeiro: Presença, 1977.

HOORNAERT, E. A cristandade durante a primeira época colonial. In: HOORNAERT, E., AZZI, R.. História da Igreja no Brasil. Petrópolis: Vozes, 1979. tomo 2.

JOSAPHAT, Carlos, frei. Las Casas. Todos os direitos para todos. São Paulo: Edições Loyola, 2000. 
MARQUES, João Francisco. "A religião na expansão portuguesa. Vectores e itinerários da evangelização ultramarina: o paradigma do Congo". Revista de História das Idéias. Coimbra, vol. 14, 1992.

MARQUESE, Rafael de Bivar. Feitores do corpo, missionários da mente: senhores, letrados e o controle dos escravos nas Américas, 1660-1860. São Paulo: Companhia das Letras, 2004.

NETO, José Alves de Freitas. Bartolomé de las Casas: a narrativa trágica, o amor cristão e a memória americana. São Paulo: Annablume, 2003.

PAGALDAY, José Ramon I., pe. "Bartolomeu de Las Casas e o seu conceito de evangelização”. In: História da Evangelização na América Latina. São Paulo: Paulinas, 1988.

PÉREZ FERNÁNDEZ, Isacio, pe. Bartolomé de Las Casas: viajero por dos mundo. Su figura, su biografia sincera, su personalidad. Cuzco: CBC, 1998.

. "Estudo preliminar". In: CASAS, Bartolomé de las. Brevíssima relação da destruição de África. Lisboa: Edições Antígona, 1996.

PALACIOS PRECIADO, Jorge. La esclavitud de los africanos y la trata de negros. Entre teoría y la práctica. Tunja: Publicaciones del Magister en Historia - UPTC, 1998. (Nuevas lecturas de Historia, 2)

RESTREPO, Luis Fernando. "Los límites da la razón occidental: la 'naturaleza' muisca y los proyectos intelectuales de los jesuitas en el Nuevo Reino de Granada, siglo XVII". In: MILLONES Figueroa, Luis, LEDEZMA, Domingo (eds.) El saber de los jesuitas, historias natulares y el Nuevo Mundo. Frankfurt/Madrid: Vervuert/Iberoamaericana, 2005.

RODRIGUES, Adriano Vasco. "Aculturação artística e social no Reino do Congo resultante da evangelização após a chegada dos portugueses". In: Atas do congresso internacional Bartolomeu Dias e a sua época. Porto: Universidade do Porto/Comissão Nacional para as Comemorações dos Descobrimentos Portugueses, 1992. v. 5. SANDOVAL, Alonso de. De instauranda athiopum salute. Madrid: Por Alonso de Paredes, 1647. (Cd Afro-América: textos históricos. Introdução e seleção de Enriqueta Vila Vilar. Coleção Clássicos Tavera, dirigido por José Andrés-Gallego. Fundação Histórica Tavera. Série II, v. 7)

. Un tratado sobre la esclavitud. [De instauranda Æthiopum salute] (introdução, transcrição e tradução de Enriqueta Vila Vilar) Madrid: Alianza Editorial, 1987.

SARANYANA, Josep Ignasi (dir.). Teología en América Latina. Desde los orígenes a la Guerra de Sucesión (1493-1715). Madrid/Frankfurt am Main: Iberoamericana/ Vervuert, 1999. v. 1. 
SAUNDERS, A. C. de C. M. História social dos escravos e libertos negros em Portugal (1441-1555). Lisboa, Imprensa Nacional/Casa da Moeda, 1982.

SUESS, Paulo (org.). A conquista espiritual da América espanhola. Petrópolis: Vozes, 1992.

THOMAS, Hugh. Quién es quién de los conquistadores. Espanha: Salvat, 2001. TODOROV, T. A conquista da América: a questão do outro. São Paulo: Martins Fontes, 1988.

VAINFAS, R. "Deus contra Palmares. Representações senhoriais e idéias jesuíticas”. In: REIS, J.J., GOMES, F. dos S.. Liberdade por um fio. São Paulo: Companhia das Letras, 1996. p. 60-80.

- El proyecto de una esclavitud cristiana: ideas jesuiticas en Brasil y Cartagena de Indias durante el siglo XVII. Medellín, X Congreso de Historia de Colombia, 1997. mimeo.

XIRAU, Ramón. Idea y querella de la Nueva España. Madrid: Alianza Editorial, 1973.

\section{Resumo}

A proposta do artigo é analisar a contribuição do dominicano Bartolomé de Las Casas, no século XVI, e do jesuita Alonso de Sandoval, no século XVII, na construção do discurso legitimador e regulador do tráfico e da escravidão dos negros.

Palavras-chave: Colonização da América espanhola; Evangelização dos negros; Escravidão negra.

\section{Abstract}

The aim of this paper is to analyze the contributions made by the Dominican Bartolomé de Las Casas, in the XVI century, and the Jesuit Alonso de Sandoval, in the XVII century, to legitimatize and regularize discourses about the slave trade and black slavery in the Spanish Americas.

Key-words: Colonization of the Hispanic America; Evangelize of blacks; Black slavery. 